\title{
Investigating Language Learning Strategies Used by Good and Poor Learners In E- Learning Class
}

\author{
Dwi Prastiani Virgonita ${ }^{1}$, Endang Fauziati², Endang Setyaningsih ${ }^{3}$
}

\begin{tabular}{l} 
A R T I C L E I NF O \\
\hline Article History: \\
Received 10.06 .2020 \\
Received in revised form \\
05.02 .2021 \\
Accepted \\
Available online \\
01.04.2021
\end{tabular}

\begin{abstract}
This study focused on English language learning strategies used by good and poor learners in elearning class during The Covid-19 pandemic. It investigated the similarity and differences of their learning strategies. Moreover, it investigated deeply factors that affected the preference of their learning strategies. It revealed that good and poor learners used all six learning strategies proposed by Oxford. Almost half of the good and poor learners used social strategy. However, most good learners used metacognitive strategies. While most poor learners used effective strategies. The lowest influencing strategy of good learners was social strategy. While the lowest influencing strategy of poor learners was metacognitive strategy. The Learning strategy preferences of good learners were affected by some factors such as belief, degree of awareness, learning style, motivation, and purpose of the learning language. The learning strategy preferences of poor learners were also affected by those factors except the purpose of the learning language.
\end{abstract}

(C) IJERE. All rights reserved

Keywords: ${ }^{1}$

E-learning, language learning strategy, poor learner, good learner.

\section{INTRODUCTION}

Learning strategies are particular ways of processing information that develop comprehension, learning, or retention of information (O'Malley \& Chamot, 1990). Learning strategies are the techniques and activities that teachers will require their students to engage in master the content (Schmeck,1988: 59). Teachers need to evaluate the way students prefer learning strategy or processing information. By investigating the language learning strategies used by the students, teachers will be able to develop strategies that will enhance the students' learning potential. Leading the students into suitable learning strategies will help them become more independent. Many kinds of research stated that there is a close relationship between high strategy use and high achievement or success in language learning (Hariyani, Ahmad \& Marsitin,2021; Griffiths, 2008; Muza,2021; Oxford, 1990; O'Malley \& Chamot, 1990; Wenden: 1987). Successful language learners can be defines as effective, efficient, good learners, or high achieving learners who reach the goal of language learning. Rubin (1975) states that good language learners get the advantage of their practice opportunities. Good language learners have a strong willingness to communicate, practice their skills, monitor their own and the speech of others, and attend to meaning. On the other hand, Vann \& Abraham (1990) explains that poor, ineffective, unsuccessful, or low achieving learners are the learners who fail to learn or move relatively slowly through an English program.

Technology has served many easy ways for both teachers and learners in language learning acquisition. One of the technology benefits is information accessibility. It gives possibility and changes of the learning condition from face-to face traditional class to e-learning or web-based learning. A learning system which is based on formalized teaching but using the support of electronic resources is defined as e-learning. Elearning means a learning that is utilizing electronic technologies to access educational curriculum outside of a traditional classroom. The development of Computer hardware and software over the past several decades leads e-learning transformation to one learning platform that enables learners to interact not only with the learning materials but also with teachers and other learners (Holmes \& Gardner, 2006). E-learning applications or software become media for students and teachers to discuss, express opinions, share their knowledge each other, and motivate the learning. Besides, students are able to use the Internet to access upto-date and relevant learning materials that they need. However, e-learning does not only give benefits for

\footnotetext{
Corresponding e-mail: dwi.virgonita@student.uns.ac.id, orcid.org/0000-0002-5034-7745, University of Sebelas Maret ${ }^{2}$ endang.fauziati@ums.ac.id, orcid.org/ 0000-0001-8621-1412,University of Muhammadiyah Surakarta

${ }^{3}$ endang_setyaningsih@staff.uns.ac.id, orcid.org/ 0000-0001-9394-1966, University of Sebelas Maret
} 
student, it also gives challenges for all learning participants because the situation between traditional classroom and e-learning environment is very different.

In 2020, in the situation of Covid-19 pandemic, The Ministry of Education and Culture in Indonesia has decided to perform the school learning activities electronically, known as SPADA (Online Learning System). Teachers and students are stressed to conduct e-learning classes (Diana Novita, 2020). The school system in Indonesia has not been well familiar with e-learning. Thus, it presents new experiences and challenges for all education components, especially students and teachers. With all the limitations and obstacles, students and teachers in senior high school can conduct e-learning. The English teachers in senior high school stated that students reach various levels of achievement during e-learning class. Thus, this research is significant since the result will provide information on how learners acquire the knowledge to reach satisfying results. The results of investigating the language learning strategies used by good and poor learners in the e-learning class are expected to benefit the academic institution in providing a suitable syllabus and supportive facilitation. It will benefit the teachers in choosing the best material, and effective teaching strategies; and the students in increasing their use of learning strategies to maximize their learning opportunities and increase their learning motivation.

The study attempts to answer the following questions:

1. What are the language learning strategies used by good learners in e-learning class?

2. What are the language learning strategies used by poor learners in e-learning class?

3. What are the similarities of the language learning strategies used by good and poor learners in elearning class?

4. What are the differences of the language learning strategies used by good and poor learners in elearning class?

5. What factors do affect the preference of language learning strategies used by good and poor learners in e-learning class?

\section{Methodology}

Design

The design of this research was a case study. The data were collected directly from research participants in the form of questionnaire, audio recordings, interview transcripts, and field notes. The study was conducted in one of Senior High Schools in East Java, Indonesia in the academic year of 2019/2020. It is one of public schools that has good reputation in academic in East Java, Indonesia. Since March 2020, this school has used e-learning system for their classes. The students consist of first, second, and third grade. The participants of this study were selected by purposive sampling. They were the second-grade students that consist of 6 good language learners and 6 poor language learners who were actively involved in e-learning class. All the participants were seventeen years old and in the second grade of Senior High School level.

\section{Instruments}

\section{Questionnaire}

Questionnaire is one of the instruments in collecting the data needed. the researcher spread a set of questionnaires to the respondents for getting the data of the language learning strategies used by good and poor learners. Meanwhile, the data of students' achievement were taken from the students' report result from the teacher. The kind of questionnaire used in this research was open-ended questionnaire which allowed the respondents to give a totally free answer. This questionnaire was expected to represent their feeling, beliefs, attitudes, opinion, behavior, or knowledge of situation (Labaw, 1980). The researcher used Strategy Inventory of Language Learning (SILL) questionnaire which has been adaptable to the open-ended questionnaire. The questionnaire was translated into Indonesia language to avoid the misunderstanding in interpreting the questions.

\section{Interview}


The interview aims to obtain a special kind of information in which the researcher wants to find out. Silverman (2005) defines interview as an effort used to elicit respondents' perception. Thus, it is necessary to conduct an interview in order to observe behavior, feeling or how people interpret situation around them. The interview can be performed in the person-to person or group interview. The researcher conducted the person-to person interview. The interview was addressed to the 12 participants in order to gather the information needed by the researcher. In this research, interview was the technique for collecting detail information to solve the research questions. The data obtained from the interview supported the results questionnaire. The researcher performed semi-structured interview to obtain deep information related to their reasons in choosing the learning strategies.

\section{Data Analyses}

Bogdan and Taylor (1975) explain data analysis as a process which details an effort formally to find the theme and to formulate the work hypotheses as suggested by the data and as an effort to give a help the theme and the work hypotheses. It can be summarized that the data analysis a process to arrange and to organize the data into a category, structure, and unit of basic explanation in order to find the theme and can be formulated by the data. The data analysis of this research consists of four main steps which is developed by Miles and Huberman (2014). The steps are data collection, data reduction, data display, drawing conclusion and verification.

\section{Results}

\section{Results of the First Question}

\section{Language Learning Strategies Used by Good Language Learners in E-learning Class}

The SILL (Strategy Inventory of Language Learning) questionnaire revealed that good language learners in e-learning class used all the types of language learning strategies but in different percentages. More than half of good learners in e-learning class used memory strategy, cognitive strategy, compensation strategy, and effective strategy. Nearly all good learners in e-learning class used metacognitive strategy, and nearly half of good learners in e-learning class used social strategy. Five of six learning strategies were used by more than half of good learners to support their learning in e-learning class. They had a high awareness of the learning strategies needed to handle their learning difficulties and support the class meetings' limitations during the e-learning class. $63 \%$ of good learners in e-learning class used memory strategy. Memory strategy supported good learners to link target language items or concepts with one another. They created mental linkages of the target language, applied images and sounds to process the information, reviewed, and employed action to comprehend and memorize the target language. $65 \%$ of good learners in e-learning class used cognitive strategy. The cognitive strategy enabled good learners to manipulate language material in direct ways. They practiced, received, and sent messages, analyzed and reason, read structure for input and output to enlarge their target language knowledge, and made their learning process more manageable. $72 \%$ of good learners used compensation strategy. Compensation strategy helped good learners make up for the lack of knowledge. They used of mother tongue or a particular clue to guess the meaning of words. Besides, compensation strategy helped good learners to overcome their limitation in speaking and writing by using gestures, switching to mother tongue, choosing the topic, and using synonyms. $78 \%$ of good learners in e-learning class used metacognitive strategy. The metacognitive strategy supported good learners to evaluate and coordinate their language learning patterns. Good learners paid attention to the teachers' order in every task and the given materials in their google classroom. They also set a learning schedule and goals to improve their target language. Moreover, they conducted self-monitoring and self-evaluating in the process of learning. $61 \%$ of good language learners in e-learning class used the affective strategy. The affective strategy supported good learners to gain control and regulate emotions, values, and attitudes. This strategy enabled good language learners to handle their anxiety and encourage themselves in learning. $44 \%$ of good language learners in e-learning class use social strategy. The social strategy helped learners to interact with other learners. They asked questions to correct mistakes and cooperated with their classmates in finishing the tasks. Besides, online applications and social media eased them to get information related to the target language culture. Therefore, they had more interest in developing their cultural understanding. 
Table 1. The Good Language Learners' Percentage of Learning Strategy Use

\title{
Number \\ of
}

Strategy

Subjects

\begin{tabular}{cccccc} 
Memory & Cognitive & Compensation & Metacognitive & Affective & Social \\
\hline $63 \%$ & $65 \%$ & $72 \%$ & $78 \%$ & $61 \%$ & $44 \%$ \\
\hline
\end{tabular}

Results of the Second Question

Language Learning Strategies Used by Poor Language Learners in E-learning Class

Based on the result of SILL (Strategy Inventory of Language Learning) questionnaire, all poor learners used all types of learning strategies proposed by Oxford in different percentages. 37\% of poor learners in elearning class used memory strategy. Memory strategy helped the poor learners to retrieve knowledge by looking at the link of one word to another word, applying images and sounds, and reviewing materials. $38 \%$ of poor learners in e-learning class used cognitive strategy. It helped them understand and produce a new language. They translated to understand the materials and use some sources to get ideas quickly. $44 \%$ of poor language learners in e-learning class used the compensation strategy. The compensation strategy allowed learners to use language despite language gaps. They guessed the meaning of words, used gestures and synonyms, and chose topics to overcome their speaking and writing obstacles. $20 \%$ of poor learners in elearning class used metacognitive strategy. The metacognitive strategy allowed poor learners to evaluate their language learning patterns and manage the learning process. They evaluated their learning result with other learners' results to know the mistakes. $50 \%$ of poor learners in e-learning class used the affective strategy. The affective strategy helped poor learners in controlling their emotions and attitudes. Poor learners took deep breathing to decrease their anxiety during the online presentation. Besides, they encouraged themselves, such as giving rewards to themselves and making positive statements. $44 \%$ of poor language learners in e-learning class used social strategy. The social strategy enabled poor learners to communicate with other learners. They asked questions to clarify mistakes, discuss, and solve their learning obstacle together. Nearly half of poor learners in e-learning class used memory strategy, cognitive strategy, compensation strategy, and social strategy. Few of the poor learners in e-learning class used metacognitive strategy. Half of poor learners in e-learning class used the affective strategy. The poor learners used all learning strategies, and the interview showed that they already knew about learning strategies. However, the percentages of poor learners in strategy use were not high. All learning strategies were only used by less than half of poor learners. It showed that most poor language learners in e-learning class still have low interest and lack of awareness to use learning strategies.

Table 2. The Poor Language Learners' Percentage of Learning Strategy Use

\section{Number of \\ Subjects}

\author{
Strategy
}

Memory Cognitive Compensation Metacognitive Affective Social

$\begin{array}{llllll}6 & 37 \% & 38 \% & 44 \% & 20 \% & 50 \%\end{array}$




\section{Results of the Third Question}

\section{Similarities of Language Learning Strategies Used by Good and Poor Language Learners in E-learning Class}

The study showed some similarities between good and poor learners' language learning strategies in elearning class. Both good and poor learners used all learning strategies proposed by Oxford, but they were presented in a different number of presentations. From the questionnaire, it can be seen a similar number in social strategy. Nearly half of good and poor learners in e-learning class used social strategy. The social strategy is a learning strategy that allowed learners to interacts with each other and understanding the target culture and language. It showed that during the learning process in e-learning class, nearly half of good and poor learners communicated their lack to their teacher and other learners through group chat via WhatsApp, via call, and video call. They clarified their difficulties with their classmates and asked for the correct answer of their tasks using google classroom and class group chat. To develop their cultural understanding of the target language, they look for information through the internet to access online applications such as YouTube and Google. They became more attractive to the target language culture because they could visualize it from a video that they get from the internet website.

\section{Results of the Fourth Question}

\section{The Differences of Language Learning Strategies Used by Good and Poor Language Learners in E-learning Class}

There were some differences between language learning strategies used by good and poor learners in elearning class. Although both learners used all types of strategies, it can be seen that there were many different criteria result of the learning strategy used. The dominant strategy used by good learners in elearning class was the metacognitive strategy. Nearly all good learners in e-learning class used metacognitive strategy. They used a metacognitive strategy to evaluate their language learning pattern and coordinate the learning process. Besides, good learners also set a target of their learning results and considered improving their learning. They also learned from their mistakes and tried to avoid similar mistakes in the next learning. Moreover, they tried to find the learning source from internet media and social media. The facilities of internet connection and technology give opportunities for them to find learning sources by themselves. In contrast, the dominant strategy used by poor language learners in e-learning class was the affective strategy. The poor learners used affective strategy to control and regulate their emotions, attitudes, and values. They identified their anxiety level, talked about their feeling, reward themselves for satisfying results, and using positive talk. By the time they do an online presentation, they handled their anxiety by taking a deep breath and thinking positively to calm themselves. They also often called their friends to share the feeling of their learning result to relieve their disappointment in their result. Moreover, by the time they got satisfying learning result, they often rewarded themselves.

The difference also can be seen from the lowest learning strategy used by both good and poor language learners. The lowest influencing learning strategy of good learners was a social strategy. Less than half of good learners used social strategy. The online class limited their opportunity to meet the teachers and other learners directly. Thus, only a few good learners communicated with each other to discuss the target language. In comparison, the lowest influencing strategy of poor learners was the metacognitive strategy. Most of them did not set their learning process goals, evaluated their learning results, and paid attention well during their class online meeting. Thus, they often missed what the teachers explained or what other learners discussed during the online discussion.

\section{Results of the Fifth Question}

The Factors that Affect the Preferences of Language Learning Strategies Used by Good and Poor Language Learners in E-learning Class

Learners have a particular reason for employing language learning strategies. They choose their learning strategies differently, which are influenced by different factors. The questionnaire and interview data explained factors that influenced good and poor learners' strategy preference. 
a. Factors that Affect the Preferences of Language Learning Strategies Used by Good Language Learners in Elearning Class Environment

\section{Belief}

The research results showed that belief becomes the reason why good learners used cognitive and social strategies in the e-learning class environment. They believed that by imitating the way of a native speaker's utterance, other people can understand their utterance as well. Thus, they tend to learn short videos of native from social media or YouTube. They watched and repeated the dialogue of those videos to practice their speaking. Besides, belief also became the reason of good learners preferred social strategy. They believed that interacting with other learners helped them understanding and improving their target language ability. They felt more comfortable by asking their difficulties to their friends. They discussed their difficulties with their classmates by group chat, phone call, and video call. When their friends were not able to answer the difficulties, they asked for help from their teacher. They believed that the teacher could help them answer all the difficulties.

\section{Degree of awareness}

The second factor was degree awareness. Based on the result, degree awareness became the reason why good learners preferred memory strategy, cognitive strategy, compensation strategy, and metacognitive strategy. The good learners used memory strategy, cognitive strategy, compensation strategy, and metacognitive strategy because they realized that those help them memorizing and understanding the target language. The good learners in the e-learning class realized that those strategies could help them memorizing and understanding the target language easier. Thus, they preferred those strategies.

\section{Learning style}

Learning style was also the factor that influences learning strategies' preferences of memory strategy, cognitive strategy, metacognitive strategy, and social strategy. Learning style influenced almost all kinds of language learning strategies. The learning styles of kinesthetic, writing/reading, audio, and visual affected learning strategy preference. Kinesthetic learners employed action in their memory strategy. The audio and visual learners used movies, songs, social media, and online applications to produce a cognitive strategy. In contrast, the writing/reading learners used online media to produce their metacognitive strategy. Some learners who got bored easily use technology and internet media to find an interesting way of their language learning. Moreover, learning style also affected good learners to use social strategy. The audio learners used internet media to develop their cultural understanding through videos.

\section{Motivation}

Next factor was motivation. Motivation influenced the learning strategies' preferences of metacognitive and affective strategy. Good learners motivated themselves by giving rewards of satisfying learning results. They also motivated themselves when they failed to reach a satisfying learning result. They said to themselves that they could do better in the next learning. This factor influenced their decision in the preference of metacognitive and affective strategy. This factor had a positive impact on the learning process of a good language learner.

\section{Purpose of the learning language}

While the last factor was the purpose of learning language, it affected the good learners to choose a metacognitive strategy. Good learners preferred metacognitive strategy to reach a satisfying target language because of their purpose of the learning language. They wanted to school abroad and got some scholarships. They had to conquer the target language first in order to get a scholarship and school abroad. 
b. Factors that Affect the Preferences of Language Learning Strategies Used by Poor Language Learners in Elearning Class

\section{Belief}

In e-learning class environment, belief affected the learning strategy preference of poor learners. This factor affected the preferences of cognitive strategy, metacognitive strategy, affective strategy, and social strategy. The poor learners believed by listening and having conversation with native speaker, they could speak as well as native speaker. They also had a belief that they would understand the target language by the help of their friends and teachers.

\section{Degree of awareness}

The degree of awareness influenced the preferences of all learning strategies. The poor learners preferred memory strategy, cognitive strategy, compensation strategy, metacognitive strategy, affective strategy, and social strategy because they understood the importance of those strategies. They realized that learning strategies eased their learning process in grabbing the target language.

\section{Learning style}

Learning style affected the preference of memory strategy, cognitive strategy, and compensation strategy. Poor learners preferred those strategies because of their learning style. Using pictures, sound, writing, and reading help them to grab the target language easily. They also visualized the target language's situation because it eased them to understand and memorize the target language.

\section{Motivation}

Motivation affected the preferences of affective strategy and social strategy. The poor learners used affective strategy and social strategy to motivate themselves in grabbing the target language. They decreased their anxiety when they spoke English to calm themselves to produce the target language fluently. They also wrote the feeling of their learning result in a diary. They motivated themselves to practice their ability with other learners in order to reach a satisfying result. Motivation affected the preferences of affective strategy and social strategy. The poor learners used affective strategy and social strategy to motivate themselves in grabbing the target language. They decreased their anxiety when they spoke English to calm themselves so they could produce the target language fluently. They also wrote their felling of their learning result in diary. They motivated themselves to practice their ability with other learners in order to reach satisfying result.

\section{DISCUSSION}

The research results revealed that good and poor learners employed all six different learning strategies proposed by Oxford; memory, cognitive, compensation, metacognitive, affective, and social strategies to develop English as the subject of the study in the e-learning class. The number of good learners in the elearning class who employed the learning strategies was higher than the number of poor learners who employed the learning strategies. It proves that if learners want to get a satisfying result in learning, they must employ a learning strategy. It is in line with the findings of Solak \& Cakir (2015) who suggested that learning language strategies positively affected academic achievement, including an online learning environment. Their study indicated that learners benefit from many types of strategies while learning English through e-learning. Good language learners had high motivation and effective use of learning strategies, positive personality, and positive beliefs in their learning process. Besides, both good learners in face-to-face class and e-learning class showed those similar characteristics. It is supported by Pages (2015). Page (2015) suggested that success in acquiring a foreign language can be explained in terms of high motivation, high amount of time devoted to learning outside the school setting, the necessary and sufficient use of learning strategies, personality, and positive language learning beliefs. 
The results of the interview showed that most of poor learners did not use language learning strategies because of unattractiveness to what they were doing. They had less motivation to learn English and the purpose of learning the language. Some previous study showed similar results. Alderman (2003) defines poor performance as a lack of motivation, lack of effort, and lack of effective learning strategies. While Chang (2010) explains that the factors to low achievement as laziness, boredom, unwillingness to work, or unattractiveness to what they are doing. Besides, Normazidah, Koo, \& Hazita (2012) states that the characteristics of low achievers as learners that regard English as a difficult subject to learn. They depend on the teacher as an authority, have less support to use English in an environment outside the classroom, get less exposure to the target language, have a limitation of vocabulary, and have less motivation to learn English. This study also showed that more than half of good learners employ the cognitive strategy. However, only almost half of poor learners employed cognitive strategies. Besides, almost all good learners used the metacognitive strategy, but only a few poor learners used the metacognitive strategy. However, only a few poor learners employed self-monitoring, while all good learners employed self-monitoring. It is in line with the findings of Kuama (2016) who revealed significant differences between successful and unsuccessful learners in cognitive and metacognitive strategies. The study also revealed the factors that influence the chosen learning strategies. Good language learners are affected by belief, degree of awareness, learning style, motivation, and purpose of the learning language. Poor language learners are affected by belief, degree of awareness, learning style, and motivation.

\section{Recommendations}

In light of the findings of the current study, the study recommends the following:

1. For the English learners

E-learning at the school level in Indonesia is still unfamiliar. Students at school have to adapt their learning way to improve their English skills. This new situation challenges them to learn independently. Thus, they have to find the effective strategies to enhance their skills. Both good and poor learners need to understand how important language learning strategies are to their study results. The strategies employed by good learners can be advice for the poor learners. The poor learners can try the learning way of the good learners in improving the target language.

2. For the English teachers and curriculum developers

It was found that only a few poor learners employed learning strategies in their e-learning. Most of them did not use learning strategies because of less motivation and purpose of learning the language. Thus, it is suggested that teachers should encourage the learners to take advantage of technology in learning English. The teacher should motivate the learners to benefit the facility of technology in elearning and convince the learners, especially the poor learners, that English skills are highly needed to compete in globalization. Besides, the teachers should provide an outlook of the advantages in learning English and how English skills may support their success in future.

The findings of this research also can be used by the teachers and curriculum developers as knowledge how learners absorb the target language in e-learning class. So, teachers can choose the most effective of teaching way and to facilitate their learning need in e-learning class to reach the goal of the learning. While curriculum developers should modify and include the activities that will involve the learners in actual use of the target language in e-learning class.

3. For the further researchers

More researches need to be conducted to know the most effective learning strategies and the obstacles faced by the learners in e-learning class. Further researcher needs to use types of e-learning strategies to analyze the strategy methods of the e-learners more deeply. Besides, it will be better for next researcher to conduct further research in a more specific term. Further research can be dealing with particular terms as reading, listening, speaking, and writing skills.

There are specific limitations to this study, which can be summarized as the following:

1. Thematic limitations: The study is limited to the language learning strategies used by good and poor learners in e-learning class.

2. Time limitations: This study was conducted in the second grade of the academic year 2019-2020. 
3. Spatial limitations: The study was applied to senior high school - the public school in East Java, Indonesia.

4. Human limitations: The study was restricted to some good and poor language learners in the second grade of Senior High School - the public school in East Java, Indonesia.

\section{References}

Alderman, M. K. (2008). Motivation for achievement: Possibilities for teaching and learning. New York: Routledge.

Arkorful, V. \& Abaidoo, N. (2014). The role of e-learning, the advantages and disadvantages of its adoption in higher education. International Journal of Education and Research, 2(12). 397-410.

Bogdan, Robert, and Steven, J., Taylor. (1975). Introduction to Qualitative Research Methods: A Phenomenological Approach to the Social Sciences. New York: Wiley.

Chang, Y.-P. (2010). A study of efl college students' self- handicapping and English performance. Procedia-Social and Behavioral Sciences, 2(2), 2006-2010.

Diana Novita, A. R. H. (2020). Plus minus penggunaan Aplikasi-Aplikasi pembelajaran daring selama pandemi Covid-19. Unimed Medan, June, 1-11.

Ellis, R. 1994. The study of second language acquisition. Oxford: Oxford University Press.

Fee, K. (2009). Delivering e-learning: A complete strategy for design, application, and assessment. London: Kogan Page.

Gan, Z., Humphreys, G., \& Hamp-Lyons. (2004). Understanding successful and unsuccessful EFL Students in Chinese universities. The Modern Language Journal, 88:229-44.

Griffiths, C. (2008). Lessons from good language learners. Cambridge: Cambridge University Press.

Halbach, A. (2000). Finding out about students' learning strategies by looking at their diaries: a case study. System. 28(1), 85-96.

Hariyani,S. Ahmad,N.J.\&Marsitin,R. (2021). Mathematics teaching practicum for junior high school in a different culture-based situation. The Universal Academic Research Journal,3(2),77-86.

Holmes, B. \& Gardner, J. (2006). E-learning: Concepts and practice. London: SAGE Publications.

Khan, B. (2005). Managing e-learning strategies: Design, delivery, Implementation and Evaluation. Hershey, PA, USA: Idea Group Inc.

Kuama, S., \& Intharaksa, U. (2016). University students' perceptions of an online English language course. Proceedings of ICHiSS 2016: 8th International Conference on Humanities and Social Sciences. National Defence University of Malaysia (pp 226-336). Selangor, Malaysia.

Labaw, P.J .(1980). Advanced questionnaire design. Cambridge, MA: Abt Books.

Liang, T. (2009). Language learning strategies: The theoretical framework and some suggestions for learner training practice. English Language Teaching,2(4), 199-206.

Liu, Y., \& Wang, H. (2009). A comparative study on e-learning technologies and products: from the East to the West. Systems Research \& Behavioral Science, 26(2), 191-209.

Miles and Huberman. (2014). Analisis data kualitatif. Jakarta: UI Press.

Moleong, Lexy J. (2001). Metodologi penelitian kualitatif. Bandung: Remaja Rosdakarya.

Muza,S.H.(2021). Team teaching approach on academic performance of students in faculty of education. The Universal Academic Research Journal,2(2),58-63

Normazidah, C. M., Koo, Y. L., \& Hazita, A. (2012). Exploring English language learning and teaching in Malaysia. Gema Online Journal of Language Studies, 12(1), 35-55.

O' Malley, J. M. and Chamot, A. U. (1990). Learning strategies in second language acquisition. Cambridge: Cambridge University Press. 
Oxford, R. L. (1989). Use of language learning strategies: A synthesis of studies with implications for strategy training, System, 17, 235-247.

Oxford, R. (1990). Language learning strategies: What every teacher should know. Boston: Heinle \& Heinle.

Rubin, J (1975). What the 'good language learner' can teach us. Tesol Quarterly, 9,41-51.

Samperio, N. (2019). Learning strategies used by high and low achievers in the first level of English. Profile: Issues in Teachers' Professional Development, 21(1), 75-89.

Schemeck, R. R. (Ed.) (1988). Learning strategies and learning styles. New York, NY: Plenum Press.

Skylar, A. (2009). A comparison of asynchronous online text-based lectures and synchronous interactive web conferencing lectures. Issues in Teacher Education, 18, 69-84.

Solak, E., \& Cakir, R. (2015). Language learning strategies of language e-learners in Turkey. E-Learning and Digital Media, 12(1), 107-120.

Pages, M. (2015). Successful and unsuccessful english learners: The use of learning strategies as an indicator of L2 (lack of Success).

Vann, R. J., \& Abraham, R. G. (1990). Strategies of unsuccessful language learners. TESOL Quarterly, 24(2) 177-198.

Wenden, A. L. (1987a). Conceptual background and utility. In A. L. Wenden \& J. Rubin (Eds.), Learner Strategies in Language Learning (pp. 3-13). Englewood Cliffs, NJ: Prentice-Hall.

Wen, Q., \& Johnson, R. K. (1997). 12 learner variables and English achievement: A study of tertiary-level English majors in China. Applied Linguistics, 18(1), 27-48. 